мая и начало июня, которые называют «Пешпазак». Также, фенологические фазы в зависимости от высоты над ур, моря отстают приблизительно на месяц [4].

Среди интродуцентов наибольшей продуктивностью выделяются Еревани, Венгерский, ХурмаиНиже приводим краткую характеристику некоторых местных и интродуцированных сортов и форм абрикоса.

Форма Аджирх-Махмури. Форм описана в к.Басид Бартангской долины. Плоды крупные, массой - 37 г. Созревают во второй декаде августа. Крона раскидистой формы, диаметром 5м. Окраска кожицы при созревании зелено-желтого цвета. Форма кроны раскидистая, диаметр кроны 5м. При полном созревание плоды вскрываются и косточки опадают. Плоды крупного размера (51x4бх43 мм), удлиненной формы, слегка сжаты с боков, с вдавленной вершиной. Брюшной шов открыт. Кожица на плодах желтая. Плоды универсального типа пользования. Мякоть бледная, плотная и среднесочная, сахаристая. Косточка отделяется хорошо, крупного размера-32х27x11мм, светлая, плоской овальной формы, вершина клиновидная. Центральное ребро сильно оттянутое, боковые ребра по всей длине довольно широкие, спинной шов закрытый. Поверхность шероховатая. Ядро сладкое, составляет 21,4% от веса косточек.

Листья имеют широко-яйцевидные форму размером 92х70 мм. Верхушка заостренная и основание клиновидное. Черешок длинный - 52 мм. Высота прироста составляет 11,0 см, его толщина - 0,2 мм. Для данной формы дополнительного селектирования не требуется.

Форма Чихох-1. Самая крупноплодная форма среди абрикосов, описанных нами в верхнем Ванче. Форма описана на приусадебном участке Азизшоева Давлятбоя. Высота дерева достигает 3 м, форма кроны раскидистая, диаметр кроны 2,5 м, Дерево описано в возрасте 6 лет. Плоды крупные 51x 45х50 мм, весом 60 г, овальные. Окраска кожицы плода светло-желтая. Мякоть желтая, сочная, сладкая. Брюшной шов выражен слабо.

Косточки среднего размера $21 \times 15 \times 12$ мм, весом 1,6 г, вес косточек составляет 2,6 \% от веса плода. Отличительным признаком этой формы является то, что в каждой косточке имеются по 2 ядра. . Косточки имеют овальную форму. Боковые ребра выражены слабо, центральное ребро оттянутое. Брюшной шов закрытый, на его поверхности имеются дырочки.

$$
* * *
$$

1. Акназаров О.А. Памир: От субтропиков до подножия ледников // Душанбе: АН РТ. Отд. биол. и мед. наук, Ассоц.”Женщины науки Таджикистана", 2000.- 42 с.

2. Ковалев Н.С. Абрикос. - М.: Сельхозиздат, 1963.- 288c.

3. Корзинников Ю.С, Юсуфбеков Х.Ю, Корзинникова Е.Г. Первичные итоги изучения сортов абрикоса в Памирском ботаническом саду // Инструкция растений и ботанические исследования в Горном Бадахшане-Душанбе .1984-С. 110-157.

4. Саодаткадамова Т.М., Фелалиев А.С. Абрикосы Памира. Душанбе, -Дониш, 2009.-175 с.

\title{
Тарасова A.O. \\ Влияние льняного жмыха в рационах молодняка лошадей на жирнокислотный состав мышечной ткани
}

ФГБОУ ВО «Курганская ГСХА имени Т.С.Мальцева»

(Россия, Курган)

doi: $10.18411 / s r-10-04-2021-17$

\section{Аннотация}

Целью работы являлось изучение жирнокислотного состава мышечной ткани молодняка лошадей, потреблявшего льняной жмых в дозировках 300 и 500 г/гол в сутки. При исследовании жирнокислотного состава липидов мышечной ткани молодняка лошадей, потреблявших льняной жмых, идентифицировано 34 жирные 
кислоты. Не установлено существенных (достоверных) различий в соотношении отдельных жирных кислот, ненасыщенных, насыщенных и полиненасыщенных между животными подопытных групп. Мясо лошадей, потреблявших льняной жмых, было более сбалансированным по содержанию жирных кислот.

Ключевые слова: льняной жмых, рационы, молодняк лошадей, мышечная ткань, жирные кислоты

\section{Abstract}

The aim of the work was to study the fatty acid composition of the muscle tissue of young horses that consumed flaxseed meals in the dosages of 300 and $500 \mathrm{~g} / \mathrm{unit}$ per day. While examining the fatty acid composition of the muscle tissue lipids of young horses consuming flaxseed meal, 34 fatty acids were identified. There were no significant (reliable) differences in the ratio of individual fatty acids, unsaturated ones, saturated ones, and polyunsaturated ones between the animals of the experimental groups. The meat of horses consuming flaxseed meals was more balanced in terms of the content of fatty acids.

Keywords: flaxseed meal, rations, young horses, muscle tissue, fatty acids

«Использование льна способствует решению белковой проблемы в животноводстве. Льняной жмых - ценный энергонасыщенный корм для всех видов сельскохозяйственных животных. Количественный и качественный состав протеина льна свидетельствует о перспективности его применения в качестве источников белка. Введение льняного жмыха в рацион животных позволяет сбалансировать его по протеину, жиру и незаменимым аминокислотам. Питательные вещества льняного жмыха легко усваиваются животными, повышают продуктивность, он благотворно воздействует на пищеварительную систему и здоровье животных» [1].

Для реализации генетического потенциала животных необходимо создать благоприятные условия, основным из которых является обеспечение полноценного кормления, использование различных кормовых добавок [2 - 6]. Использование кормовых добавок в рационах лошадей способствует увеличению продуктивности и улучшению физиологического состояния животных $[7,8,9]$. В последние годы во всем мире возрос интерес к использованию льна и продуктов его переработки. В практике кормления сельскохозяйственных животных льняной жмых признается одним из лучших.

Целью работы являлось изучение показателей жирнокислотного состава мышечной ткани молодняка лошадей русской тяжеловозной породы при использовании льняного жмыха в составе рационов.

Научно-хозяйственный опыт провели в ООО «Логиново» Курганской области на молодняке лошадей русской тяжеловозной породы. Опыт провели на молодняке в возрасте с 9 до 12 месяцев. Контрольная группа молодняка получала основной рацион, 1 опытная - рацион с добавлением льняного жмыха в дозировке 300 г/гол, а 2 опытной 500 г/гол в сутки. Полученный в опытах цифровой материал подвергли биометрической обработке [10]. Разницу считали достоверной при $\mathrm{P} \leq 0,05$.

В таблице 1 приведены данные по содержанию жирных кислот в мышечной ткани молодняка лошадей. При исследовании жирнокислотного состава липидов мышечной ткани молодняка лошадей подопытных групп идентифицировано 34 жирные кислоты. Исследованиями не установлено существенных (достоверных) различий в соотношении отдельных жирных кислот, ненасыщенных, насыщенных и полиненасыщенных между животными подопытных групп. Во всех группах молодняка установлено равное количество жирных кислот: капроновая, каприловая, деценовая, тридекановая, гептадекановая, нондекановая, эйкозатриеновая, 
бегеновая, эруковая, докозапентеновая, тетракозеновая. Установлено большее содержание каприновой (на $0,05 \%$ ), лауриновой (на 0,14 и 0,21 \%), миристиновой (на 0,90 и 0,70 \%), миристолеиновой (на 0,05 и 0,08 \%), пентадекановой (на 0,14 \%), цис-10-пентадеценовой (на $0,03 \%$ ), пальмитиновой (на 1,10 и $0,50 \%$ ), пальмитолеиновой (на 1,50 и 1,80\%), олеиновой (на 7,70 и 3,90\%), $\alpha$-линоленовой (на $1,30 \%$ ), эйкозадиеновой (на 0,40 и $0,10 \%$ ), эйкозапентеновой (на 0 и $0,30 \%$ ), генейкозановой (на $0,50 \%$ ), докозагексановой (на 0,20 и 0,35 \%) в мышечной ткани молодняка контрольной группы.

Таблийа 1.

Жирнокислотный состав мышеечной ткани молодняка лошадей, \% ( $\overline{\mathrm{X}} \pm \mathrm{S} \overline{\mathrm{x}})$

\begin{tabular}{|c|c|c|c|}
\hline \multirow{2}{*}{ Кислота } & \multicolumn{3}{|c|}{ Группа } \\
\hline & контрольная & 1 опытная & 2 опытная \\
\hline Капроновая & 0,05 & 0,05 & 0,05 \\
\hline Каприловая & 0,05 & 0,05 & 0,05 \\
\hline Каприновая & 0,15 & 0,10 & 0,10 \\
\hline Деценовая & 0,05 & 0,05 & 0,05 \\
\hline Лауриновая & 0,62 & 0,48 & 0,41 \\
\hline Тридекановая & 0,05 & 0,05 & 0,05 \\
\hline Миристиновая & 3,70 & 2,80 & 3,00 \\
\hline Миристолеиновая & 0,20 & 0,15 & 0,12 \\
\hline Пентадекановая & 0,40 & 0,26 & 0,26 \\
\hline Цис-10-пентадеценовая & 0,13 & 0,10 & 0,10 \\
\hline Пальмитиновая & 26,10 & 25,00 & 25,60 \\
\hline Пальмитолеиновая & 4,50 & 3,00 & 2,70 \\
\hline Гептадекановая & 0,49 & 0,50 & 0,50 \\
\hline Гептадеценовая & 0,34 & 0,60 & 0,25 \\
\hline Стеариновая & 6,90 & 9,10 & 8,20 \\
\hline Олеиновая & 27,9 & 20,20 & 24,00 \\
\hline Элаидиновая & 2,10 & 2,30 & 1,70 \\
\hline Ленолевая & 18,3 & 26,00 & 18,5 \\
\hline$\gamma$-Линоленовая & 0,20 & 0,50 & 0,50 \\
\hline$\alpha$-Линоленовая & 3,00 & 1,70 & 1,70 \\
\hline Нондекановая & 0,05 & 0,05 & 0,05 \\
\hline Гондоиновая & 0,05 & 0,40 & 0,35 \\
\hline Арахиновая & 0,20 & 0,10 & 0,20 \\
\hline Эйкозадиеновая & 0,60 & 0,20 & 0,50 \\
\hline Эйкозатриеновая & 0,05 & 0,05 & 0,05 \\
\hline Арахидоновая & 1,15 & 2,20 & 2,70 \\
\hline Эйкозапентеновая & 0,60 & 0,60 & 0,30 \\
\hline Генейкозановая & 0,60 & 0,10 & 0,10 \\
\hline Бегеновая & 0,20 & 0,20 & 0,20 \\
\hline Эруковая & 0,05 & 0,05 & 0,05 \\
\hline Докозапентеновая & 0,05 & 0,05 & 0,05 \\
\hline Докозагексановая & 0,40 & 0,20 & 0,05 \\
\hline Лигноцериновая & 1,70 & 2,10 & 2,40 \\
\hline Тетракозеновая & 0,05 & 0,05 & 0,05 \\
\hline
\end{tabular}

При этом внутримышечный жир в контроле отличался более низким содержанием стеариновой (на 2,20 и 1,30 \%), ленолевой (на 7,70 и 0,20 \%), $\gamma$ линоленовой (на $0,30 \%$ ), гондоиновой (на 0,35 и 0,30\%), арахидоновой (на 1,05 и $1,55 \%)$, лигноцериновой $(0,20$ и $0,35 \%)$.

Таким образом, исследования, полученные в эксперименте, указывают, что мясо лошадей, потреблявших льняной жмых, было более сбалансированным по содержанию жирных кислот. 
масличный,

его

хозяйственно-полезные

качества

//http://www.rsnso.ru/directions/ensuring_quality/publications/?n=805

2. Суханова С.Ф., Азаубаева Г.С., Лещук Т.Л. Степень влияния внешних факторов на показатели функционирования биологических систем // Вестник Курганской ГСХА. - 2017. - № 2 (22). - С. 65-69.

3. Суханова С.Ф., Азаубаева Г.С., Лещук Т.Л. Определение степени влияния внешних факторов на биологические системы // Методы механики в решении инженерных задач: Материалы I Всероссийской науч.-практич. конференции 12 октября 2017 г. - Курган: Изд-во Курганской ГCXА, 2017. - С. 136 - 144.

4. Суханова С.Ф., Лещук Т.Л. Степень влияния некоторых факторов на показатели функционирования живых систем // Актуальные проблемы экологии и природопользования: сборник статей по материалам Всероссийской (национальной) научно-практической конференции. - Курган: Изд-во Курганской ГСХА, 2018. - С.169 - 175.

5. Суханова С.Ф. Внешние факторы, определяющие функционирование биологических систем //Биотехнологические аспекты управления технологиями пищевых продуктов в условиях международной конкуренции: Сб. статей по материалам Всероссийской (национальной)научнопрактической конференции (19 марта 2019 г) - Курган: Изд-во Курганской ГСХА, 2019. - С.407 412.

6. Суханова С.Ф. Изучение корреляционных связей в биологическом объекте под действием кормового фактора // Научное обеспечение безопасности и качества продукции животноводства: сб. статей по материалам III Всероссийской (национальной) научно-практической конференции (23 мая 2019 г). - Курган: Изд-во Курганской ГСХА, 2019. - С. 274-283.

7. Суханова С.Ф. Использование препаратов Сел-Плекс и Кайод в рационах кобыл // Актуальные проблемы и научное обеспечение развития современного животноводства: сборник статей по материалам Всероссийской (национальной) научно-практической конференции (11 апреля 2019 г.) - Курган: Изд-во Курганской ГСХА, 2019. - С. 106 - 112.

8. Тарасова А.О., Суханова С.Ф. Показатели неспецифического иммунитета молодняка лошадей, потреблявших различные дозировки льняного жмыха //The Scientific Heritage. - 2020. - № 55-3 (55). - C. 14-18.

9. Sukhanova S., Pozdnyakova N., Tarasova A. Impact of Linseed Cake in the Diet of Russian Heavy Draft Horses on Productive and Physiological Indicators // Advances in engineering research (International scientific and practical conference "AgroSMART - Smart solutions for agriculture" (AgroSMART 2018). - Vol.151, 2018. - p.p.679 - 684.

10. Суханова С.Ф., Азаубаева Г.С., Лещук Т.Л., Кощаев А.Г. Биометрические методы в животноводстве. - Краснодар: КубГАУ, 2017. - 162 с.

\section{Тарасова A.O. \\ Показатели неспецефической резистентности у лошадей, потреблявших льняной жмых}

ФГБОУ ВО «Курганская ГСХА имени Т.С.Мальщева»

(Россия, Курган)

doi: $10.18411 / \mathrm{sr}-10-04-2021-18$

\section{Аннотация}

Приводятся результаты исследований по изучению влияния различных дозировок льняного жмыха на показатели неспецифической резистентности у молодняка лошадей 9 - 12 месячного возраста по периодам опыта (в начале опыта, в середине и в конце опыта). Установлено, что у молодняка лошадей опытных групп, получавших в составе рациона льняной жмых, отмечалась более устойчивая неспецифическая резистентность, о чем свидетельствовали фагоцитарные реакции этих животных. Это выражается в общем укреплении организма, повышении его защитных возможностей в борьбе с различными возбудителями болезней.

Ключевые слова: льняной жмых, рационы, молодняк лошадей, неспецифическая резистентность 